\author{
Marquette University \\ e-Publications@Marquette
}

$12-2009$

\title{
The Incidence of Tobacco Taxation: Evidence from Geographic Micro-Level Data
}

Andrew Hanson

Marquette University, andrew.r.hanson@marquette.edu

Ryan Sullivan

Syracuse University

Follow this and additional works at: https://epublications.marquette.edu/econ_fac

Part of the Economics Commons

\section{Recommended Citation}

Hanson, Andrew and Sullivan, Ryan, "The Incidence of Tobacco Taxation: Evidence from Geographic Micro-Level Data" (2009). Economics Faculty Research and Publications. 447.

https://epublications.marquette.edu/econ_fac/447 


\section{The Incidence of Tobacco Taxation: Evidence from Geographic Micro-Level Data}

\section{Andrew Hanson}

Department of

Economics, Georgia

State University, Atlanta, GA 30302

and

\section{Ryan Sullivan \\ Department of Economics, Syracuse University, Syracuse, NY 13244}

\section{National Tax Journal Vol. LXII, No. 4 December 2009}

\begin{abstract}
This paper uses a recent increase in Wisconsin's tobacco tax as a natural experiment to measure the economic incidence of tobacco taxation, using micro-level data on cigarette prices from retail locations in Wisconsin and states that share its border. We find that Wisconsin's \$1 tobacco tax increase was over-shifted to consumers; they pay the entire amount of the tax as well as a premium of between 8-17 cents per pack of cigarettes. We also use geo-coded data to test if the incidence of the tobacco tax is different for locations near the border of states with different tobacco taxation.
\end{abstract}

\section{INTRODUCTION}

$\mathrm{T}$ obacco taxation is an important revenue source at the state and federal level, and as a matter of policy is also intended to reduce tobacco consumption. The federal government collected over $\$ 7.7$ billion in revenue from tobacco taxes in $2006^{1}$, while state governments in the aggregate collect an additional $\$ 15.2$ billion annually in tobacco taxes. ${ }^{2} \mathrm{~A}$ key component to understanding how effective a tobacco tax is at reducing consumption ${ }^{3}$ is how the economic incidence of the tax is split between consumers and producers. If the full burden of a tobacco tax is passed on to consumers in the form of higher prices it is more likely to discourage consumption,

1 See U.S. Department of the Treasury, Alcohol and Tobacco Tax and Trade Bureau, “Cumulative Summary, Fiscal Year 2006," http://www.ttb.gov/ statistics/final06.pdf.

2 See U.S. Census Bureau, "State Government Tax Collections," http:/ / www.census.gov/govs/www/statetax.html. This figure does not include additional sales taxes collected on tobacco.

3 The economic justification for government intervention in the market for tobacco products is that tobacco use (especially smoking tobacco) causes a negative externality. For studies that measure the external effects of tobacco use see Shoven, Sundberg, and Bunker (1989), Manning et al. (1989, 1991), Gravelle and Zimmerman (1994), Viscusi (1995, 2002), Evans, Ringel, and Stech (1999), Cutler et al. (2000), and Sloan et al. (2004). For studies that measure the mortality cost per pack see Gruber and Koszegi (2001), Cutler (2002), Sloan et al. (2004), and Viscusi and Hersch (2008). There have been a wide variety of studies that analyze the demand for cigarettes, notably Becker, Grossman, and Murphy (1994), Evans, Ringel, and Stech (1999), and Gruber and Koszegi (2001). For a comprehensive review of studies on cigarette demand see Chaloupka and Warner (2000). 
and may be a more regressive tax because tobacco users tend to be low income individuals. ${ }^{4}$

Estimates of the incidence of tobacco and cigarette taxation find a wide range of results; from the tax burden being overshifted to consumers (they pay the full tax plus a premium on top of the tax amount) to concluding that tobacco taxes do not raise prices by the amount of the tax. Harris (1987) and Keeler et al. (1996) both provide evidence using state level data that show the burden of tobacco taxation is over-shifted to consumers, although their estimates of the amount of overshifting differ dramatically. Sumner and Wohlgenant (1985) estimate that only the amount of the tax is passed on to consumers, while Ashenfelter and Sullivan (1987) suggest that excise tax increases do not consistently act to increase retail prices.

We estimate how the economic burden of a tobacco tax is divided between retail suppliers of cigarettes and consumers by examining the price response to a recent $\$ 1$ change in Wisconsin's state cigarette tax. Our estimates have several advantages over previous estimates of tobacco tax incidence. First, we use micro-level data from retail locations matched to both city and county taxes, instead of relying on state-year variation (which cannot account for different city and county tax rates). Second, we analyze an isolated policy change that offers clean identification of the effects of the tobacco tax increase on retail prices. Third, our data come from an extremely short time window and relatively small geographic area, so we do not have to correct for inflation over time or adjust for cost of living across areas. Finally, our data are geo-coded so we are able to test the price responsiveness of retailers that are near a bordering state where the tax treatment of tobacco sales is different.
We find that the $\$ 1$ tax increase results in a statistically significant retail price increase of between $\$ 1.08-1.17$ depending on the econometric specification we use, the type of cigarettes, and the type of retail establishment. We find consistent evidence of over-shifting across both panel and repeated cross-section econometric specifications, and for both name brand and generic cigarettes. We also show that the amount of over-shifting is sensitive to how far the retail establishment is from the Wisconsin border and the state border in question, although these results are somewhat imprecise. Stores near the Minnesota border (where the tobacco tax is lower after the law change) do not have as large of an over-shifting premium. Stores near the Michigan border (where the tobacco tax is higher before and after the law change) have a larger over-shifting premium.

We first give the details of Wisconsin's tobacco tax change, and lay out our identification strategy for estimating the incidence of tobacco taxation. Section III provides a description of our unique micro-level data on cigarette prices at retail establishments. Section IV presents and discusses our regression results for estimating the incidence of tobacco taxation; it also includes a discussion of potential criticisms of our methodology. The final section of the paper concludes.

\section{POLICY CHANGE BACKGROUND AND IDENTIFICATION STRATEGY}

We use a recent increase in the tax on cigarettes in the state of Wisconsin as a natural experiment to identify the incidence of tobacco taxation. Beginning January 1, 2008, Wisconsin increased the state tax on cigarettes by $\$ 1$, from 77 cents to $\$ 1.77$ per pack. ${ }^{5}$ While the cigarette tax

\footnotetext{
4 For a review of this literature see Poterba (1989), Fullerton and Metcalf (2002), and Gravelle (2007).

5 WI Act 20, amend sec. 139.31(1) (a) and (b), signed into law on October 26, 2007.
} 
increased by over 125 percent in Wisconsin at the start of $2008,{ }^{6}$ the states that share a border with Wisconsin did not change their tax treatments of cigarettes at that time. Table 1 shows the tax on cigarettes in Wisconsin and the surrounding states before and after the tax increase took effect. As shown in Table 1, Wisconsin went from having the lowest tax on cigarettes to having the second highest in the group of states that share its border.

We use the differential change in Wisconsin and absence of change in states that share its border to identify how the tax affects the retail tax inclusive price, and thus measure the incidence of the tax. The policy change we analyze reflects a substantial tax increase compared to other recent tobacco tax changes. Since January 1, 2000 there have been 83 separate state level cigarette tax increases, ${ }^{7}$ with

Table 1

State Cigarette Tax Package

\begin{tabular}{|c|c|c|}
\hline & December ‘07 & January ‘ 08 \\
\hline Illinois $^{1,2,3}$ & $\$ 0.98$ & $\$ 0.98$ \\
\hline Iowa ${ }^{3}$ & $\$ 1.36$ & $\$ 1.36$ \\
\hline Michigan & $\$ 2.00$ & $\$ 2.00$ \\
\hline Minnesota & $\$ 1.485$ & $\$ 1.485$ \\
\hline Wisconsin ${ }^{3}$ & $\$ 0.77$ & $\$ 1.77$ \\
\hline
\end{tabular}

\section{Notes:}

${ }^{1}$ Cook County, IL has an additional $\$ 2$ per pack tax on cigarettes.

${ }^{2}$ The City of Chicago has an additional 68 cents per pack tax on cigarettes.

${ }^{3} \mathrm{WI}, \mathrm{IL}$, and IA have different sales tax rates by city and county, we include these rates, as well as state rates for $\mathrm{MN}$ and $\mathrm{MI}$ in our analysis. A complete listing of sales tax rates used for all 270 cities in our sample is available from the authors upon request.

Source: Federation of Tax Administrators, "Cigarette Tax Increases 2000-2008," http://www.taxadmin. org/fta/rate/cig_inc02.html a median increase of 39 cents per pack. Wisconsin's \$1 increase matches the largest one time tobacco tax increase by any state since $2000 .^{8}$

We use a difference-in-differences (D-D) approach to identify the retail price response to the cigarette tax change. We compare the difference in the retail price of cigarettes in Wisconsin with surrounding states before the tax change (December, 2007) with the difference in prices between Wisconsin and surrounding states after the tax change (January, 2008). The main advantage of using this method is that it controls for any fixed characteristics of Wisconsin as well as any time trends in all states that may also affect cigarette prices.

Using the D-D method requires two primary assumptions. The first is that there are no factors other than the tax increase that affect the change in cigarette prices between December, 2007 and January, 2008 in Wisconsin. This assumption seems particularly reasonable given that the time elapsed between our data points is at most 42 days. The second assumption is that prices in our control states (IA, IL, MI, and MN) are not affected by the policy change in Wisconsin. Our data show that this assumption is not violated on average, as the price change in our control states is less than 1 cent for the full sample.

We implement the D-D identification strategy using both data from a panel and repeated cross sections of retail cigarette venders. The regression used to determine

\footnotetext{
6 We expect an immediate response in the retail price of cigarettes on January 1, 2008 because of the way the new tax is collected. According to conversations with administrators at the Wisconsin Department of Revenue, the Wisconsin tobacco tax increase was also levied on inventories of cigarettes at the retail level on January 1, 2008. Store owners were required to pay the new tax on all cigarettes in inventory as of January 1, 2008. Although this raises some concerns about the price response of retailers prior to the tax change, it means that we expect an immediate price response when the tax is enacted.

7 Oregon is the only state to decrease the tobacco tax during this time period, doing so by 10 cents at the beginning of 2004. See Federation of Tax Administrators, "Cigarette Tax Increases 2000-2008," http:/ / www.taxadmin. org/fta/rate/cig_inc02.html.

8 Since 2000 Iowa, Maine, Maryland, Montana, South Dakota, and Texas also increased the tax per pack of cigarettes by $\$ 1$.
} 
the effect of the tax increase using the panel data is:

$$
\left(P_{i, j a n}-P_{i, d e c}\right)=\alpha+\beta_{1}(\text { Wisconsin })+\varepsilon_{i}
$$

where Wisconsin is a dummy variable equal to one if the store is located in that state, and $P_{i, j a n}$ and $P_{i, d e c}$ are the tax inclusive price of cigarettes for store $i$ in January and December. Analyzing a panel of stores and using the change in price as our dependent variable means that we control for any attributes of the store that remain constant between December, 2007 and January, 2008 such as the type of retail establishment (for example whether the store is a convenience or grocery store) and its location. Because we have information about the type of retail establishment, we run regressions for (1) using our entire panel as well as separate regressions for the various types of establishments, and for stores that are within a short distance of the state border.

The parameter of interest in (1) is $\beta_{1^{\prime}}$ which shows how the $\$ 1$ tax increase in Wisconsin affects the change in cigarette prices. If $\beta_{1}<1$, this implies that the full burden of the tax is not passed on to consumers, as some of the tax burden falls on cigarette retailers. If $\beta_{1}=1$, then the burden of the cigarette tax increase is fully borne by consumers in the form of higher prices. If $\beta$ $>1$, the tax on cigarettes is "over-shifted" to consumers, as they bear the entire burden of the tax and pay a premium above the tax amount. If the tax is over-shifted to consumers, it is likely that the retail market for cigarettes is imperfect. ${ }^{9}$

We also implement the D-D identification strategy using a repeated cross section of stores in our data. This strategy allows us to use all stores for which we have price data on in at least one time period (December or January). The regression used to determine the effect of the tax increase using the repeated cross section of stores is:

$$
\begin{aligned}
& P_{i, t}=\alpha+\beta_{1}(\text { Wisconsin })+\beta_{2}(\text { January }) \\
& \quad+\beta_{3}(\text { Wisconsin * January })+Z i^{\prime} \gamma+\varepsilon_{i}
\end{aligned}
$$

where, as in the panel regression, Wiscon$\sin$ is a dummy variable equal to one if the store is located in that state. For cross-section identification, $P_{i, t}$ is the tax inclusive price from store $i$ in time period $t$, where $t$ is either December, 2007 or January, 2008. January is a dummy variable equal to one if the observation is from the period after the tax increase. $Z$ is a vector of control variables that includes a dummy variable indicating whether the store is a national retailer, a dummy variable indicating if the store is a tobacco-only retailer, a convenience store, or a grocery store. $Z$ also includes a dummy variable for the state level location of the store. The coefficient of interest in (2) is $\beta_{3}$, which has the same interpretation as $\beta_{1}$ in (1).

\section{DATA}

Our data come from telephone surveys of cigarette retailers at tobacco specialty, grocery, and convenience stores in Wisconsin, Illinois, Minnesota, Iowa, and the upper peninsula of Michigan. We created a list of 1,542 stores that sell cigarettes in these states using phone book listings and internet searches by geography. ${ }^{10}$ We contacted each establishment in December, 2007 (before the tax increase) and again in January, 2008 (after the tax increase) to request the retail price of cigarettes.

9 For a detailed discussion of theoretical models of tax incidence that produce over-shifting see Fullerton and Metcalf (2002).

10 We created the majority of our store list using an internet search engine by searching "tobacco store" and "convenience store" by geography for each state in our sample. This search provided the store name, phone number, and address for the stores in our sample. 
We implemented the first phase of surveys between December 17, 2007 and December 23, 2007. In the pre-tax change wave, 70 percent of stores provided price information, for a total of 1,072 data points. ${ }^{11}$ We implemented the second phase of surveys between January 9, 2008 and January 28, 2008. A total of 1,107 stores provided cigarette price information in the post-tax change phase, a 72 percent response rate. ${ }^{12}$ We created our panel using the 65 percent of stores on our list (1,002 stores) that provided price information in both the pre-tax change and post-tax change phases.

We requested price information on two types of cigarettes from the stores in our survey-a premium brand and generic brand. ${ }^{13}$ Our survey consisted of the following questions:

- "What is the price per pack of Name Brand Cigarettes?"

- "Does that price of Name Brand cigarettes include the sales and tobacco tax?"
- "What is the price per pack of Generic Brand Cigarettes?"

- "Does that price of Generic Brand cigarettes include the sales and tobacco tax?"

A total of 614 (57 percent) out of the 1,072 stores that gave price information for the name brand cigarettes in the first phase also gave price information for the generic brand cigarettes. In the second phase, 641 (58 percent) out of the 1,107 stores that gave price information on the name brand also gave price information on the generic brand. ${ }^{14}$

In the first phase of our survey, about 28 percent of stores from which we were not able to obtain price information actively refused to give the price of cigarettes. In the second phase about 26 percent of stores from which we were not able to obtain price information actively refused to give the price of cigarettes. ${ }^{15}$ Table 2 highlights the difference in stores that refused to give price information with those that responded to our survey. As

Table 2

Comparison of Survey Respondents and Refusals

\begin{tabular}{lcccccrrr}
\hline & \multicolumn{3}{c}{ December } & & \multicolumn{3}{c}{ January } \\
\cline { 2 - 3 } & Respondents & Refused & & $\begin{array}{c}\text { Percent } \\
\text { Refusing }\end{array}$ & & Respondents & Refused & $\begin{array}{r}\text { Percent } \\
\text { Refusing }\end{array}$ \\
\hline Convenience & 809 & 108 & 11.78 & & 835 & 101 & 10.79 \\
Grocer & 156 & 17 & 9.83 & & 157 & 6 & 3.68 \\
Tobacco & 107 & 9 & 7.76 & & 115 & 8 & 6.50 \\
Chain & 434 & 77 & 15.07 & & 455 & 66 & 12.67 \\
\hline
\end{tabular}

Note: The refusal rate is calculated as the number who actively refused to give price information divided by the number who responded plus the number who refused.

11 In the first wave of surveys, 470 "stores" did not yield price information. Of these, 68 did not sell cigarettes, 82 were either a wrong phone number or a disconnected line, 134 refused to give cigarette price information over the phone, 163 did not answer our calls, and the remaining 23 were not used because of various reliability concerns.

12 In the second wave of surveys, 435 "stores" did not yield price information. Of these, 40 did not sell cigarettes, 94 were either a wrong number or a disconnected line, 115 refused to give cigarette price information over the phone, 137 did not answer our calls, and the remaining 49 were not used because of various reliability concerns.

13 To keep consistent across locations we asked for the same name and generic brand from each store surveyed.

14 According to conversations with the Wisconsin and Minnesota Departments of revenue the total number of cigarette retailers in those states is about 13,000 and 9,500, respectively (including bars and restaurants). Administrators in Iowa, Michigan, and Illinois were not able to provide an estimate of the number of cigarette retailers.

15 Note that the share of stores that actively refused to give price information was a small share of the total stores that we contacted -8 percent in the first phase and 7 percent in the second phase. 
the table shows, convenience stores were more likely to actively refuse to give price information than both grocery and tobacco-only stores. Also, stores that were national chains were more likely to actively refuse than other stores. Because there are differences in the response rate across the type of stores, we are careful to account for store type in our estimation strategy.

We merged information on state, county, and city sales taxes, gathered from each state's department of revenue, ${ }^{16}$ with our price data to calculate the taxinclusive price for each observation. ${ }^{17}$ Wisconsin, Illinois, and Iowa have different sales tax rates across cities, while cities in the upper peninsula of Michigan all have a 6 percent sales tax rate. In addition to the state of Illinois tobacco taxes, Cook County, IL has a \$2 tax per pack, and the city of Chicago has a 68 cents tax per pack. We contacted each state department of revenue (as well as city and county where appropriate) to ensure that there were no other changes, besides the $\$ 1$ per pack increase in Wisconsin, made to sales or cigarette taxes between December 17, 2007 and January 28, 2008 for the cities in our sample.

We classified the stores in our data by retail establishment type based on the store name. We classified stores as tobacco specialty, grocery, or convenience stores. We were also able to differentiate those that were national chain stores from local or regional establishments. Out of the 1,002 stores in our panel data, 101 (10 percent) are tobacco specialty stores, 148 (15 percent) are grocery stores, and the remaining 753 (75 percent) are convenience stores. About 40 percent (406 stores) are national chain retailers.
In addition to information about the type of retail establishment, we also have the street address for each store in our sample. We use GIS software to calculate the distance from the Wisconsin border for each store in our sample. Of the stores in our sample we were able to locate 941 (94 percent) of the addresses exactly. For the remaining 6 percent of stores that we could not match exactly, we use the center of the city or zip code where the store is located to measure the distance to the nearest Wisconsin border. Tables 3 and 4 show how our sample of stores varies by both the average distance to the Wisconsin border and for stores within five miles of the border across all states.

Table 3 (name brand) and Table 4 (generic) provide a summary of our price data across several dimensions. The average price of name brand cigarettes in the pre-tax change survey is $\$ 4.36$ per pack. Importantly for our identification strategy, the average price for name brand cigarettes in our control states (IL, MN, MI, IA) did not change by more than 6 cents (MI). The average price of generic brand cigarettes in the pre-tax change survey is $\$ 3.83$. In the post tax-change survey, the average price of generic brand cigarettes increased by 46 cents to $\$ 4.29$. The average price of the generic brand cigarettes changed fairly substantially in two of our control states, which violates one of our identification assumptions for difference-in-differences estimation. The average price of the generic brand cigarettes increased by 14 cents in Illinois, and by 10 cents in Michigan.

Table 3 (name brand) and Table 4 (generic) also show how our price data differs for stores that are within five miles of the Wisconsin state border. As Table 3

16 State, county, and city sales tax rates are available at: (1) Illinois Department of Revenue, "Tax Rate Finder," http:/ /www.revenue.state.il.us/; (2) Iowa Department of Revenue, "Sales Tax Rate Look Up," http:/ /www. iowa.gov/tax; (3) Michigan Department of Revenue, "Taxes," http://www.michigan.gov/treasury; Minnesota Department of Revenue, "Sales and Use Tax," http://www.taxes.state.mn.us/; (4) Wisconsin Department of Revenue, "Tax Rates," http://www.dor.state.wi.us/.

17 The sales tax rates used to calculate the tax-inclusive prices are available from the authors upon request. 
Table 3

Summary Statistics for Name Brand Cigarettes

\begin{tabular}{|c|c|c|c|c|c|c|}
\hline & Wisconsin & Illinois & Minnesota & Michigan & Iowa & $\begin{array}{l}\text { All } \\
\text { States }\end{array}$ \\
\hline \multicolumn{7}{|l|}{ December 2007 Survey } \\
\hline Average price $(\$)$ & 3.87 & 4.92 & 4.31 & 5.16 & 4.89 & 4.36 \\
\hline Standard deviation (Price) & $(0.29)$ & $(1.49)$ & $(0.25)$ & $(0.35)$ & $(0.42)$ & $(0.89)$ \\
\hline Minimum price $(\$)$ & 3.41 & 3.70 & 3.97 & 4.31 & 4.19 & 3.41 \\
\hline Maximum price $(\$)$ & 5.00 & 8.93 & 5.40 & 6.10 & 5.60 & 8.93 \\
\hline Average distance to WI border (miles) & 35.84 & 76.08 & 38.69 & 33.09 & 88.38 & 50.65 \\
\hline Number of stores within 5 miles of WI border & 87 & 32 & 43 & 20 & 18 & 200 \\
\hline Average border store price $(\$)$ & 3.82 & 4.26 & 4.32 & 4.96 & 4.64 & 4.18 \\
\hline Average non-border store price (\$) & 3.88 & 5.02 & 4.30 & 5.25 & 4.94 & 4.40 \\
\hline Average convenience store price (\$) & 3.86 & 5.01 & 4.30 & 5.14 & 5.02 & 4.36 \\
\hline Number of convenience stores & 369 & 143 & 156 & 54 & 87 & 809 \\
\hline Average grocery store price (\$) & 3.96 & 5.30 & 4.39 & 5.32 & 4.88 & 4.51 \\
\hline Number of grocery stores & 68 & 43 & 31 & 6 & 8 & 156 \\
\hline Average tobacco store price $(\$)$ & 3.81 & 4.27 & 4.18 & NA & 4.39 & 4.16 \\
\hline Number of tobacco stores & 29 & 46 & 10 & 0 & 22 & 107 \\
\hline Average national chain store price $(\$)$ & 3.86 & 5.30 & 4.25 & 4.98 & 5.01 & 4.38 \\
\hline Number of national chain stores & 197 & 72 & 89 & 32 & 44 & 434 \\
\hline Number of respondents & 466 & 232 & 197 & 60 & 117 & 1,072 \\
\hline \multicolumn{7}{|l|}{ January 2008 Survey } \\
\hline Average price $(\$)$ & 5.00 & 4.88 & 4.32 & 5.22 & 4.89 & 4.85 \\
\hline Standard deviation (Price) & $(0.33)$ & $(1.45)$ & $(0.29)$ & $(0.40)$ & $(0.43)$ & $(0.79)$ \\
\hline Minimum price $(\$)$ & 3.80 & 3.72 & 4.05 & 4.23 & 3.69 & 3.69 \\
\hline Maximum price $(\$)$ & 6.63 & 8.93 & 5.40 & 6.47 & 5.55 & 8.93 \\
\hline Average distance to WI border (miles) & 35.62 & 80.14 & 38.17 & 34.25 & 88.64 & 51.90 \\
\hline Number of stores within 5 miles of WI border & 88 & 33 & 49 & 20 & 19 & 209 \\
\hline Average border store price $(\$)$ & 4.95 & 4.24 & 4.36 & 4.99 & 4.70 & 4.68 \\
\hline Average non-border store price (\$) & 5.01 & 4.99 & 4.30 & 5.32 & 4.93 & 4.89 \\
\hline Average convenience store price (\$) & 4.99 & 4.98 & 4.31 & 5.21 & 5.01 & 4.87 \\
\hline Number of convenience stores & 363 & 153 & 167 & 59 & 93 & 835 \\
\hline Average grocery store price (\$) & 5.10 & 5.21 & 4.37 & 5.35 & 4.81 & 4.98 \\
\hline Number of grocery stores & 70 & 42 & 31 & 5 & 9 & 157 \\
\hline Average tobacco store price (\$) & 4.89 & 4.33 & 4.24 & NA & 4.42 & 4.49 \\
\hline Number of tobacco stores & 31 & 51 & 10 & 0 & 23 & 115 \\
\hline Average national chain store price $(\$)$ & 5.00 & 5.31 & 4.23 & 5.01 & 5.01 & 4.89 \\
\hline Number of national chain stores & 201 & 79 & 96 & 33 & 46 & 455 \\
\hline Number of respondents & 464 & 246 & 208 & 64 & 125 & 1,107 \\
\hline
\end{tabular}

shows, the average price of name brand cigarettes at stores within five miles of the Wisconsin border is less than the average price for stores further from the border in all states except Minnesota. In 2008, the discount for stores near the border is largest in Illinois, where stores within five miles of the Wisconsin border have an average price that is about 75 cents less than other stores in the state. The border discount in 2008 is also substantial in Michigan and Iowa, where stores within five miles of the Wisconsin border have an average price that is between $23-33$ cents per pack less than other stores in those states. A similar pattern does not emerge for the price of the generic brand cigarettes at stores located within five miles of the Wisconsin border.

\section{ESTIMATES OF TOBACCO TAX INCIDENCE}

Using our unique micro level data on the retail price of cigarettes in Wisconsin and surrounding states, we can make several comparisons that allow us to identify the economic incidence of the tobacco tax increase. Figure 1 shows a visual representation of the price changes that occur between December, 2007 (before the tax increase) and January, 2008 (after the tax 
Table 4

Summary Statistics for Generic Brand Cigarettes

\begin{tabular}{|c|c|c|c|c|c|c|}
\hline & Wisconsin & Illinois & Minnesota & Michigan & Iowa & $\begin{array}{c}\text { All } \\
\text { State }\end{array}$ \\
\hline \multicolumn{7}{|l|}{ December 2007 Survey } \\
\hline Average price $(\$)$ & 3.42 & 3.79 & 3.99 & 4.51 & 4.48 & 3.83 \\
\hline Standard deviation (Price) & $(0.32)$ & $(0.33)$ & $(0.20)$ & $(0.83)$ & $(0.47)$ & $(0.52)$ \\
\hline Minimum price (\$) & 2.11 & 2.66 & 3.44 & 3.18 & 3.54 & 2.11 \\
\hline Maximum price (\$) & 4.91 & 5.03 & 4.70 & 6.51 & 5.35 & 6.51 \\
\hline Average distance to WI border (miles) & 32.02 & 95.28 & 39.27 & 30.02 & 88.51 & 53.75 \\
\hline Number of stores within 5 miles of WI border & 53 & 18 & 37 & 5 & 15 & 128 \\
\hline Average border store price $(\$)$ & 3.47 & 3.82 & 3.99 & 3.78 & 4.37 & 3.78 \\
\hline Average non-border store price (\$) & 3.41 & 3.78 & 4.00 & 4.84 & 4.50 & 3.84 \\
\hline Average convenience store price (\$) & 3.44 & 3.82 & 3.99 & 4.51 & 4.65 & 3.86 \\
\hline Number of convenience stores & 179 & 57 & 124 & 16 & 67 & 443 \\
\hline Average grocery store price $(\$)$ & 3.34 & 3.75 & 4.03 & NA & 4.43 & 3.73 \\
\hline Number of grocery stores & 35 & 20 & 25 & 0 & 8 & 88 \\
\hline Average tobacco store price $(\$)$ & 3.43 & 3.76 & 3.87 & NA & 3.98 & 3.74 \\
\hline Number of tobacco stores & 20 & 29 & 8 & 0 & 21 & 78 \\
\hline Average national chain store price $(\$)$ & 3.43 & 3.75 & 3.97 & 4.46 & 4.68 & 3.84 \\
\hline Number of national chain stores & 104 & 23 & 67 & 10 & 35 & 239 \\
\hline Number of respondents & 234 & 106 & 157 & 16 & 96 & 609 \\
\hline \multicolumn{7}{|l|}{ January 2008 Survey } \\
\hline Average price $(\$)$ & 4.58 & 3.93 & 4.03 & 4.61 & 4.50 & 4.29 \\
\hline Standard deviation (Price) & $(0.30)$ & $(0.64)$ & $(0.22)$ & $(0.62)$ & $(0.46)$ & $(0.50)$ \\
\hline Minimum price (\$) & 3.35 & 3.25 & 3.24 & 3.60 & 3.47 & 3.24 \\
\hline Maximum price $(\$)$ & 5.90 & 7.62 & 4.82 & 5.40 & 5.23 & 7.62 \\
\hline Average distance to WI border (miles) & 31.49 & 105.95 & 40.06 & 56.73 & 90.18 & 59.20 \\
\hline Number of stores within 5 miles of WI border & 51 & 21 & 44 & 1 & 15 & 132 \\
\hline Average border store price $(\$)$ & 4.60 & 3.88 & 4.04 & 3.60 & 4.37 & 4.26 \\
\hline Average non-border store price $(\$)$ & 4.57 & 3.94 & 4.03 & 4.81 & 4.52 & 4.29 \\
\hline Average convenience store price (\$) & 4.58 & 4.05 & 4.04 & 4.61 & 4.63 & 4.35 \\
\hline Number of convenience stores & 161 & 69 & 132 & 6 & 80 & 448 \\
\hline Average grocery store price $(\$)$ & 4.61 & 3.96 & 4.06 & NA & 4.47 & 4.26 \\
\hline Number of grocery stores & 29 & 19 & 29 & 0 & 7 & 84 \\
\hline Average tobacco store price $(\$)$ & 4.48 & 3.70 & 3.91 & NA & 4.03 & 4.00 \\
\hline Number of tobacco stores & 22 & 36 & 9 & 0 & 21 & 88 \\
\hline Average national chain store price $(\$)$ & 4.58 & 3.98 & 4.01 & 4.37 & 4.69 & 4.36 \\
\hline Number of national chain stores & 104 & 30 & 74 & 4 & 40 & 252 \\
\hline Number of respondents & 212 & 124 & 170 & 6 & 108 & 620 \\
\hline
\end{tabular}

increase) at the locations in our sample for both the generic and name brand cigarettes. Each dot in Figure 1 represents the price change of a retail location between December, 2007 and January, 2008. As shown by the maps in Figure 1, prices in Wisconsin increased almost universally by more than the \$1 tax for both the generic and name brand cigarettes. Figure 1 also displays how well the Border States work as a control group, as most locations in other states did not change cigarette prices at all between December, 2007 and January, 2008.

To get a precise estimate of the price response to the tax change illustrated in Figure 1, we estimate (1) and (2) using data from our survey of cigarette retailers. Regression results using the panel data estimating (1) show that not only do consumers pay the entire $\$ 1$ per pack tax increase, but they pay between a 12-17 cents premium on top of the tax increase. That is, as shown in column (1) of Table 5 , we estimate $\beta_{1}$ to be equal to about 1.12 for name brand cigarettes and about 1.17 for the generic brand using the full sample of retail locations. Both of these results are precisely estimated, as they are statistically different from zero at less than the one-percent level. The 95 percent confidence interval for the estimates in column (1) also shows that the point estimates are significantly larger than $\$ 1$, evidence that 


\section{Figure 1}

Cigarette Price Change, December 2007-January 2008
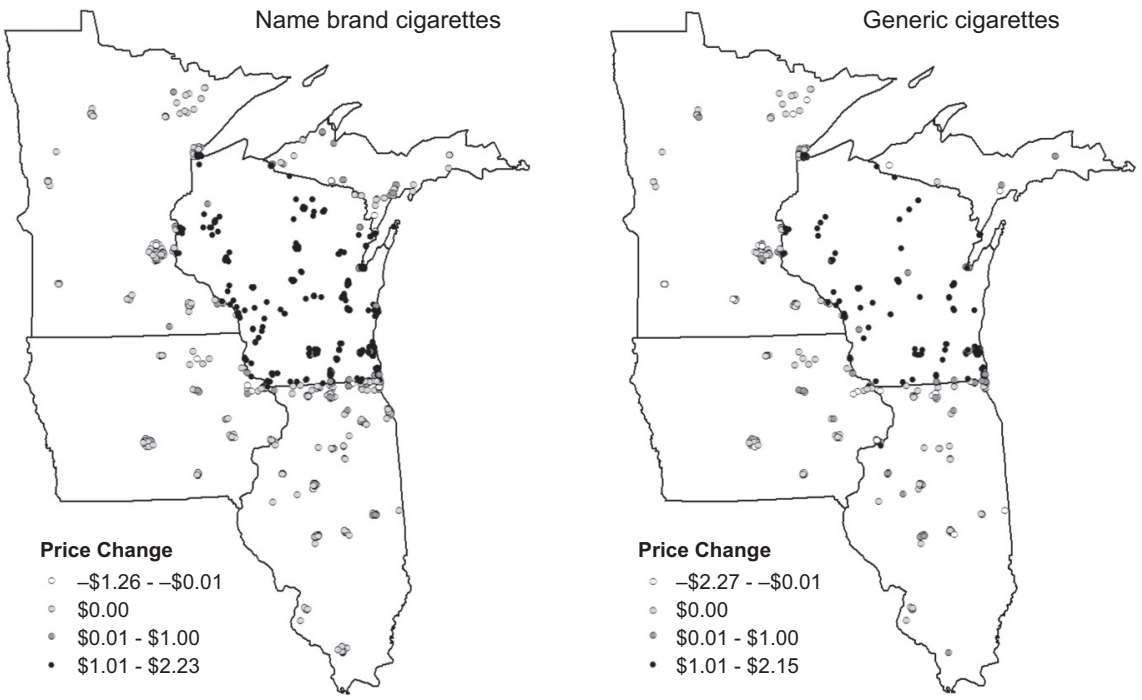

Source: Maps were created using Arcmap GIS software, and the data from a survey of cigarette retail establishments.

the tax increase caused a price increase larger than the amount of the tax.

Columns 2-5 of Table 5 show regression results for the various types of retail establishments in the panel data. These results confirm the finding that the $\$ 1$ tax per pack increase is more than passed on to consumers in the form of higher prices, and that this result is not unique to the type of retail establishment. The results for both the generic and name brand cigarettes sold at grocery and convenience stores, columns (4) and (5) of Table 5, show that $\beta_{1}$ is less than 1 cent different than the coefficient using the entire sample, indicating no unique response from these types of stores. The estimates for $\beta_{1}$ in the specification using data from stores that are tobacco specialty establishments are about $\$ 1.10$ for the name brand and about $\$ 1.13$ for the generic, roughly 3 to 4 cents less than the full sample estimates. The tobacco specialty store estimates suggest that these stores do not include as large a premium above the tax as other stores, which suggests that this type of retail store does not possess the same degree of market power that other types of stores in our survey may. ${ }^{18}$

Regression results estimating (2), shown in columns (1) and (2) of Table 6 , using the cross-section data for name brand cigarettes, reinforce the findings from the panel data estimates. Column (1) shows the cross-section results without using the indicator variables for the type of retail establishment, and column (2) shows the estimates controlling for the type of retail establishment. The coefficient of interest in each case, $\beta_{3}$, which is comparable to $\beta_{1}$ in the panel regression, is within 1 cent of the panel estimates confirming the over-shifting of the tobacco tax that we estimate in the panel regres-

\footnotetext{
18 In results not shown, we estimated (1) with interactions for the store type and the Wisconsin variable to test the hypothesis that the price change across store types is different. An F-test shows the coefficients of the interaction between store type and Wisconsin are not significantly different.
} 
Table 5

Effect of \$1 Tax Increase on Cigarette Prices, Results Using Panel Data

\begin{tabular}{lccccc}
\hline & \multicolumn{5}{c}{ Name Brand } \\
\cline { 2 - 6 } & $\begin{array}{c}\text { Full Panel } \\
(1)\end{array}$ & $\begin{array}{c}\text { National Chain } \\
(2)\end{array}$ & $\begin{array}{c}\text { Tobacco } \\
(3)\end{array}$ & $\begin{array}{c}\text { Convenience } \\
(4)\end{array}$ & $\begin{array}{c}\text { Grocery } \\
(5)\end{array}$ \\
\hline Wisconsin $\left(\beta_{1}\right)$ & $\begin{array}{c}1.1275^{* * *} \\
(0.0093)\end{array}$ & $\begin{array}{c}1.117^{* * *} \\
(0.0154)\end{array}$ & $\begin{array}{c}1.1023^{* * *} \\
(0.0455)\end{array}$ & $\begin{array}{c}1.1316^{* * *} \\
(0.0102)\end{array}$ & $\begin{array}{c}1.1313^{* * *} \\
(0.0217)\end{array}$ \\
$95 \%$ Confidence for $\beta_{1}$ & {$[1.1093,1.1458]$} & {$[1.0868,1.1472]$} & {$[1.0119,1.1926]$} & {$[1.1116,1.1516]$} & {$[1.0884,1.1742]$} \\
$\mathrm{N}$ & 1002 & 407 & 101 & 753 & 148 \\
$\mathrm{R}^{2}$ & 0.9364 & 0.9287 & 0.8555 & 0.9423 & 0.949 \\
\hline & & & & $1.1805^{* * *}$ & $1.1791^{* * *}$ \\
Wisconsin $\left(\beta_{1}\right)$ & $1.1763^{* * *}$ & $1.2081^{* * *}$ & $1.1363^{* * *}$ & $(0.0578)$ \\
& $(0.0246)$ & $(0.0391)$ & $(0.0456)$ & $(0.0309)$ & {$[1.0637,1.2946]$} \\
$95 \%$ Confidence for $\beta_{1}$ & {$[1.1279,1.2247]$} & {$[1.1308,1.2854]$} & {$[1.0452,1.2274]$} & {$[1.1197,1.2412]$} & {$[1.0637$} \\
$\mathrm{N}$ & 474 & 184 & 71 & 338 & 65 \\
$\mathrm{R}^{2}$ & 0.8287 & 0.8393 & 0.8997 & 0.8119 & 0.8687 \\
\hline Notes: Results
\end{tabular}

Notes: Results include only the sample of stores for which we have both December and January data. Sample includes stores in IA, IL, MN, WI, and the upper peninsula of MI. Asterisks denote significance at the $1 \%\left({ }^{* * *}\right)$ level.

Table 6

Effect of \$1 Tax Increase on Cigarette Prices, Results Using Repeated Cross-Section Data

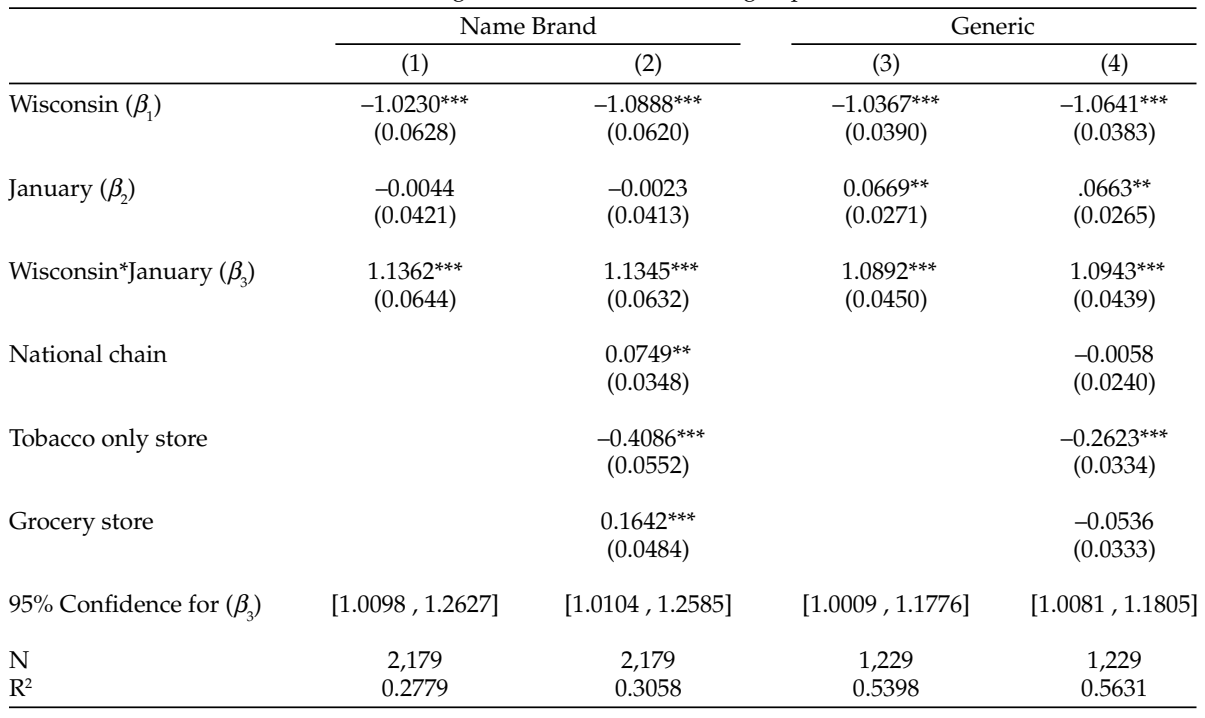

Notes: Results include the full sample of stores for which we have data on in at least one period. Sample includes stores in IA, IL, MN, WI, and the upper peninsula of MI. The convenience store dummy variable is excluded; results are not sensitive to which dummy variable is excluded. All specifications include state level dummy variables for IL, MN and MI and exclude a dummy variable for IA. The results presented for the coefficient of interest are not sensitive to the state dummy excluded. Asterisks denote significance at the $1 \%\left({ }^{* * *}\right)$ and $5 \%\left(^{* *}\right)$ levels. 
sions. The 95 percent confidence interval for each of these estimates is larger than the panel regressions; however, our results are still significantly different from zero at the 1 percent level.

Columns (3) and (4) of Table 6 show the regression results for estimating (2) using the cross-section data for the generic brand cigarettes. Column (3) shows the cross-section results without controls, and column (4) shows the results controlling for the type of retail establishment. The coefficient of interest, $\beta_{3^{\prime}}$ is quite a bit lower than the comparable $\beta_{1}$ from the panel regressions. We estimate the price increase as a result of the tax change is approximately $\$ 1.09$ for generic brand cigarettes using the repeated cross-section data, roughly 8 cents less than the estimate using the panel data. Again, these results are statistically significant at the one percent level, with the confidence interval indicating that 95 percent of the distribution is greater than \$1. Although the cross-section results for the generic brand cigarettes suggest a smaller premium than the panel results, they still show evidence of over-shifting of the tax burden on to consumers.

The difference in the coefficient estimate between the panel and repeated cross section for generic cigarettes is likely caused by the substantial decrease in the grocery store premium. As the grocery store coefficient in column (4) of Table 6 shows, grocery stores sell the generic brand cigarettes for about 5 cents less than other stores; however, the panel estimates for grocery stores indicate that they actually raised their price more than other stores. It seems that the grocery stores that responded to our survey both in January and December were more likely to have raised their price more for the generic brand cigarettes than those who responded to only one of the surveys. The coefficient for tobacco-only stores shows that stores specializing in tobacco products sell both name brand ( 40 cents) and generic (26 cents) for substantially less than the other types of stores surveyed.

\section{A. Estimates of Tobacco Tax Incidence by Geography}

Wisconsin shares a border with states that have a range of tobacco tax rates, from 98 cents-\$2. Because of the possibility for casual smuggling ${ }^{19}$ in areas close to the border, the retail cigarette market may not be confined to the state. We can test for the possibility that the incidence of the tobacco tax varies across distance from a specific state's border using our geo-coded data and altering the econometric specifications in (1) and (2). To test the effect that distance from the Wisconsin state border has on tax incidence, we group the data into stores that are within one, five, 10 , and 25 miles of each state border (IA, MN, MI, IL). We create an indicator variable equal to one for each of these groupings and run separate regressions for each distance category using panel data with following econometric specification:

$$
\begin{aligned}
& \left(P_{i, j a n}-P_{i, \text { dec }}\right) \\
& \quad=\alpha+\beta_{1}\left(\text { Inside Mile }^{*} \text { State }_{j}\right)+\varepsilon_{i}
\end{aligned}
$$

where Inside Mile is an indicator variable that is equal to one if a store is within one, five, 10 , or 25 miles of the state border, and State is a variable indicating the state border in question where $j$ references either MN, IL, IA, or MI. We estimate (3) using only stores in Wisconsin, which allows us to test the differential effect of the tax change by comparing stores closer to another state's border with stores that are further in the interior of the state. The

\footnotetext{
19 For studies on cross-border cigarette smuggling see Baltagi and Levin (1986), Gruber, Sen, and Stabile (2003), Stehr (2005), and Lovenheim (2008).
} 
coefficient of interest is $\beta_{1}$ (estimated in a separate regression for each distance and state border) which, if different from zero, tells us that stores in Wisconsin within the distance boundaries split the incidence of the tobacco tax differently with consumers than those further from the Wisconsin border. Notice that the $\beta_{1}$ coefficients in the panel specifications are not a general distance premium as the dependent variable is the change in the price of cigarettes. The results for each separate regression by distance from the state border in question are presented together in Table 7 for both the name brand and generic brand cigarettes.

As Table 7 shows, the point estimates in each separate regression for the amount of over-shifting of the tax is sensitive to being near a state border, and to the specific state border in question. For the name brand cigarettes, the only result that attains (marginal) statistical significance is for stores within 25 miles of the Illinois state border, where the over-shifting of the tax on the name brand cigarettes is about 4 cents less than stores in other parts of the state. This result suggests that stores near the Illinois state border over-shift the tax on the name brand cigarettes by about 31 percent less than the stores in the remainder of the state do.

The incidence estimation results shown in Table 7 for stores near the Wisconsin border using the generic brand cigarettes and panel data display a different pattern than the name brand results as well as a higher degree of precision. Again, we run separate regressions for each distance

Table 7

Effect of \$1 Tax Increase on Cigarette Prices By Distance to Border, Results Using Panel Data (Standard Errors in Parentheses)

\begin{tabular}{lcccc}
\hline & \multicolumn{3}{c}{ Name Brand } \\
\cline { 2 - 5 } & $\begin{array}{c}\text { MN Border } \\
(1)\end{array}$ & $\begin{array}{c}\text { IL Border } \\
(2)\end{array}$ & $\begin{array}{c}\text { MI Border } \\
(3)\end{array}$ & $\begin{array}{c}\text { IA Border } \\
(4)\end{array}$ \\
\hline Inside 1 Mile * $\operatorname{State}_{\mathrm{j}}\left(\beta_{1}\right)$ & 0.035 & -0.065 & -0.034 & -0.051 \\
& $(.035)$ & $(.071)$ & $(.042)$ & $(.112)$ \\
Inside 5 Miles * State $_{\mathrm{j}}\left(\beta_{1}\right)$ & 0.021 & -0.054 & -0.03 & 0.068 \\
& $(.028)$ & $(.036)$ & $(.033)$ & $(.060)$ \\
Inside 10 Miles * State $_{\mathrm{j}}\left(\beta_{1}\right)$ & 0.015 & -0.031 & -0.025 & 0.02 \\
& $(.027)$ & $(.026)$ & $(.031)$ & $(.048)$ \\
Inside 25 Mile * State $_{\mathrm{j}}\left(\beta_{1}\right)$ & 0.012 & $-0.04 *$ & -0.036 & 0.004 \\
& $(.025)$ & $(.022)$ & $(.030)$ & $(.037)$
\end{tabular}

$\mathrm{N}=423$ in all specifications

\begin{tabular}{|c|c|c|c|c|}
\hline \multirow[b]{2}{*}{ Inside 1 Mile * $\operatorname{State}_{\mathrm{j}}\left(\beta_{1}\right)$} & \multicolumn{4}{|c|}{ Generic } \\
\hline & $\begin{array}{c}-0.125^{* *} \\
(.062)\end{array}$ & & $\begin{array}{l}.263^{* *} \\
(.109)\end{array}$ & \\
\hline Inside 5 Miles * State $_{\mathrm{j}}\left(\beta_{1}\right)$ & $\begin{array}{c}-0.097^{*} \\
(.050)\end{array}$ & $\begin{array}{l}0.053 \\
(.103)\end{array}$ & $\begin{array}{l}.164 * \\
(.094)\end{array}$ & $\begin{array}{l}0.109 \\
(.144)\end{array}$ \\
\hline Inside 10 Miles $^{*} \operatorname{State}_{\mathrm{j}}\left(\beta_{1}\right)$ & $\begin{array}{c}-.094^{*} \\
(.049)\end{array}$ & $\begin{array}{r}-0.016 \\
(.067)\end{array}$ & $\begin{array}{l}.164^{*} \\
(.094)\end{array}$ & $\begin{array}{l}0.062 \\
(.125)\end{array}$ \\
\hline Inside 25 Miles $^{*} \operatorname{State}_{\mathrm{j}}\left(\beta_{1}\right)$ & $\begin{array}{c}-.110^{* *} \\
(.047)\end{array}$ & $\begin{array}{l}0.033 \\
(.063)\end{array}$ & $\begin{array}{l}.164^{*} \\
(.094)\end{array}$ & $\begin{array}{c}-0.021 \\
(.096)\end{array}$ \\
\hline$N=161$ in all specifications & & & & \\
\hline
\end{tabular}

Notes: Results include only the sample of stores in Wisconsin for which we have both December and January data. Results reflect separate regressions for each distance measure and each state border using only stores in Wisconsin, the $\beta_{1}$ coefficient is reported from each separate regression. Asterisks denote significance at the $5 \%\left({ }^{* *}\right)$ and $10 \%\left(^{*}\right)$ levels. 
and state border given. Column (1) in the bottom half of Table 7 shows evidence that stores near the Minnesota border over-shift the burden of the tax on the generic brand cigarettes by substantially less than stores in other parts of the state. The estimates of $\beta_{1}$ suggest that the tax is over-shifted by between 9-13 cents less than stores in other areas of the state, statistically significant at the ten or five percent level depending on the mileage in question. These estimates imply that at least 53 percent of the over-shifting premium disappears, with at most 71 percent disappearing for stores near the Minnesota border.

Column (3) in the bottom half of Table 7 shows that the over-shifting premium for the generic brand cigarettes is between 16-26 cents larger for stores near the Michigan border than in other areas of the state; the estimates of $\beta_{1}$ are statistically significant at the five or ten percent level depending on the mileage in question. The estimates by distance to the Michigan border translate into at least a 93 percent increase of the amount of over-shifting and as much as a 149 percent increase in over-shifting in comparison to other stores.

To test the effect that distance has on the incidence of tobacco taxation using cross-sectional data we use the following econometric specification, and estimate separate regressions for each distance state border pair:

$$
\begin{aligned}
& P_{i, t}=\alpha+\beta_{1}(\text { January }) \\
& \quad+\beta_{2}\left(\text { Inside Mile }^{*} \text { State }_{j}\right) \\
& +\beta_{3}\left(\text { January }^{*} \text { Inside Mile } \text { State }_{j}\right) \\
& +\mathrm{Zi}^{\prime} \gamma+\varepsilon_{i}
\end{aligned}
$$

where, as in (2), the $Z_{i}$ represents store level characteristics, State is a variable that indicates being near the state border in question, where $j$ references either $\mathrm{MN}$, IL, IA, or MI. We run the regression for (4) using data from only stores in Wisconsin. The $\beta_{3}$ coefficients are the combined effect of the tax and of being close to a specific neighboring state's border. We run separate regressions for each border and each measure of closeness to border (one, five, 10 , and 25 miles) compared to being in other areas of Wisconsin. The $\beta_{3}$ coefficients have the same interpretation as the $\beta_{1}$ coefficients in (3). The $\beta_{2}$ coefficient for the cross-section specifications provide an estimate of the general premium or discount for retail outlets near the border of a specific neighboring state (but inside of Wisconsin), which we could not obtain using the panel specification. As with the panel data, we run separate regressions for each measure of distance and each state border using the cross-section data and (4). Table 8 and 9 show estimation results of separate regressions for (4) using each measure of distance and each state border.

The incidence estimates on the name brand cigarettes for the cross-section results by distance are generally consistent with the panel data estimates. Unfortunately, these results are not estimated with much precision, as we cannot attach statistical significance to any of the $\beta_{3}$ coefficients for the name brand estimates using crosssection data. The name brand cross-section estimates do, however, produce interesting results for the $\beta_{2}$ coefficient, or the general price effect of being close to another state border. Column (1) of Table 8 shows that there is a substantial discount offered at stores in Wisconsin that are within five, 10, and 25 miles of the Minnesota state border. This discount is between 11-13 cents per pack of cigarettes and is statistically significant at the one or five percent level depending on the specification.

The other $\beta_{2}$ coefficient that is noteworthy is on the price of name brand cigarettes near the Illinois border that sell for a premium compared to other areas of the state. Column (2) of Table 8 shows that the retail price of name brand cigarettes at 
Table 8

Effect of \$1 Tax Increase on Cigarette Prices By Distance to Border, Results Using Cross-Section Data for Name Brand Cigarettes

(Standard Errors in Parentheses)

\begin{tabular}{|c|c|c|c|c|}
\hline & $\begin{array}{l}\text { MN Border } \\
\text { (1) }\end{array}$ & $\begin{array}{l}\text { IL Border } \\
\text { (2) }\end{array}$ & $\begin{array}{l}\text { MI Border } \\
\text { (3) }\end{array}$ & $\begin{array}{c}\text { IA Border } \\
(4)\end{array}$ \\
\hline Inside 1 Mile * $\operatorname{State}_{\mathrm{j}}\left(\beta_{2}\right)$ & $\begin{array}{c}-0.065 \\
(.081)\end{array}$ & $\begin{array}{l}0.176 \\
(.139)\end{array}$ & $\begin{array}{c}-0.074 \\
(.076)\end{array}$ & $\begin{array}{l}0.046 \\
(.220)\end{array}$ \\
\hline Inside 5 Miles $^{*} \operatorname{State}_{\mathrm{j}}\left(\beta_{2}\right)$ & $\begin{array}{c}-.132^{* * *} \\
(.049)\end{array}$ & $\begin{array}{l}0.065 \\
(.067)\end{array}$ & $\begin{array}{c}-0.045 \\
(.061)\end{array}$ & $\begin{array}{l}0.114 \\
(.104)\end{array}$ \\
\hline Inside 10 Miles* $^{*} \operatorname{State}_{\mathrm{j}}\left(\beta_{2}\right)$ & $\begin{array}{c}-.131^{* * *} \\
(.048)\end{array}$ & $\begin{array}{l}0.039 \\
(.049)\end{array}$ & $\begin{array}{l}-0.057 \\
(.059)\end{array}$ & $\begin{array}{l}0.112 \\
(.084)\end{array}$ \\
\hline Inside 25 Miles* $^{*}$ tate $_{\mathrm{j}}\left(\beta_{2}\right)$ & $\begin{array}{l}-.116^{* *} \\
(.045)\end{array}$ & $\begin{array}{l}.067^{*} \\
(.040)\end{array}$ & $\begin{array}{l}-0.059 \\
(.056)\end{array}$ & $\begin{array}{l}0.102 \\
(.066)\end{array}$ \\
\hline January $^{*}$ Inside 1 Mile*$^{*}$ State $_{\mathrm{j}}\left(\beta_{3}\right)$ & $\begin{array}{l}0.018 \\
(.113)\end{array}$ & $\begin{array}{c}-0.066 \\
(.197)\end{array}$ & $\begin{array}{c}-0.055 \\
(.135)\end{array}$ & $\begin{array}{c}-0.051 \\
(.311)\end{array}$ \\
\hline January $^{*}$ Inside 5 Miles $^{*}$ State $_{\mathrm{j}}\left(\beta_{3}\right)$ & $\begin{array}{l}0.038 \\
(.069)\end{array}$ & $\begin{array}{c}-0.035 \\
(.097)\end{array}$ & $\begin{array}{c}-0.074 \\
(.107)\end{array}$ & $\begin{array}{l}-0.018 \\
(.152)\end{array}$ \\
\hline January*Inside 10 Miles $^{*}$ State $_{\mathrm{j}}\left(\beta_{3}\right)$ & $\begin{array}{l}0.036 \\
(.067)\end{array}$ & $\begin{array}{r}-0.022 \\
(.070)\end{array}$ & $\begin{array}{c}-0.069 \\
(.101)\end{array}$ & $\begin{array}{c}-0.016 \\
(.121)\end{array}$ \\
\hline January*Inside 25 Miles $^{*}$ State $_{\mathrm{j}}\left(\beta_{3}\right)$ & $\begin{array}{l}0.028 \\
(.064)\end{array}$ & $\begin{array}{c}-0.025 \\
(.058)\end{array}$ & $\begin{array}{l}-0.08 \\
(.094)\end{array}$ & $\begin{array}{c}-0.047 \\
(.094)\end{array}$ \\
\hline
\end{tabular}

$\mathrm{N}=930$ in all specifications

Notes: Results include the full sample of stores for which we have data on in at least one period. All Regressions include the January indicator as well as grocery, tobacco and national chain variables, the convenience store dummy is excluded, results are not sensitive to which dummy variable is excluded. Results reflect separate regressions for each distance measure and each state border using only stores in Wisconsin, the $\beta_{2}$ and $\beta_{3}$ coefficients for a given distance and state are reported for each separate regression. Asterisks denote significance at the $\left.1 \%{ }^{(* *}\right), 5 \%\left(^{* *}\right)$, and $10 \%\left(^{*}\right)$ levels.

stores within 25 miles of the Illinois border sell for about 7 cents more than at stores in other areas of the state, statistically significant at the ten percent level.

The incidence estimates for the generic brand cigarettes using cross-section data by distance are generally not consistent with the panel data estimates or the name brand results, as shown in Table 9. None of the $\beta_{3}$ coefficients is statistically different than zero, and most of the point estimates are smaller than the panel estimates. The increase in over-shifting we found for the generic brand near the Michigan state border using the panel results does not hold up to statistical significance tests in the cross-section specification, and in some cases we find the opposite sign.

The generic brand cross-section estimates produce an interesting result for the $\beta_{2}$ coefficient on stores near the Michigan border. These results, shown in column (3) of Table 9, suggest that the general price effect of being close to the Michigan border is large and statistically significant for most specifications. The estimates of $\beta_{2}$ suggest that stores in Wisconsin within 25 miles of the Michigan border sell the generic brand cigarettes for as much as 37 cents per pack more than stores in other areas of the state.

\section{B. Explanation of Tobacco Tax Incidence Results}

Our primary estimates of the incidence of tobacco taxation are that the $\$ 1$ tax increase is over-shifted to consumers by between 8-17 cents depending on the econometric specification and the type of cigarettes. Our 
Table 9

Effect of \$1 Tax Increase on Cigarette Prices By Distance to Border, Results Using Cross-Section Data for Generic Brand Cigarettes

(Standard Errors in Parentheses)

\begin{tabular}{|c|c|c|c|c|}
\hline & $\begin{array}{l}\text { MN Border } \\
\text { (1) }\end{array}$ & $\begin{array}{l}\text { IL Border } \\
\text { (2) }\end{array}$ & $\begin{array}{l}\text { MI Border } \\
\text { (3) }\end{array}$ & $\begin{array}{c}\text { IA Border } \\
\text { (4) }\end{array}$ \\
\hline Inside 1 Mile * $\operatorname{State}_{\mathrm{j}}\left(\beta_{2}\right)$ & $\begin{array}{l}0.022 \\
(.086)\end{array}$ & $\begin{array}{c}-0.165 \\
(.311)\end{array}$ & $\begin{array}{l}0.148 \\
(.132)\end{array}$ & \\
\hline 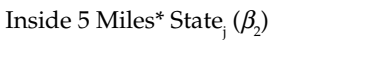 & $\begin{array}{l}0.011 \\
(.055)\end{array}$ & $\begin{array}{l}0.054 \\
(.119)\end{array}$ & $\begin{array}{l}.212^{*} \\
(.111)\end{array}$ & $\begin{array}{l}0.201 \\
(.156)\end{array}$ \\
\hline Inside 10 Miles* $^{*} \operatorname{State}_{\mathrm{j}}\left(\beta_{2}\right)$ & $\begin{array}{l}0.008 \\
(.054)\end{array}$ & $\begin{array}{l}-0.042 \\
(.076)\end{array}$ & $\begin{array}{l}.371^{* * *} \\
(.098)\end{array}$ & $\begin{array}{l}0.139 \\
(.140)\end{array}$ \\
\hline Inside 25 Miles $^{*}$ State $_{\mathrm{j}}\left(\beta_{2}\right)$ & $\begin{array}{c}-0.001 \\
(.053)\end{array}$ & $\begin{array}{c}-0.103 \\
(.068)\end{array}$ & $\begin{array}{c}.371^{* * *} \\
(.098)\end{array}$ & $\begin{array}{l}0.029 \\
(.01)\end{array}$ \\
\hline January $^{*}$ Inside 1 Mile $^{*}$ State $_{\mathrm{j}}\left(\beta_{3}\right)$ & $\begin{array}{c}-0.046 \\
(.123)\end{array}$ & & $\begin{array}{l}0.197 \\
(.296)\end{array}$ & \\
\hline January*Inside 5 Miles $^{*}$ State $_{\mathrm{j}}\left(\beta_{3}\right)$ & $\begin{array}{c}-0.054 \\
(.080)\end{array}$ & $\begin{array}{c}-0.069 \\
(.163)\end{array}$ & $\begin{array}{l}0.112 \\
(.208)\end{array}$ & $\begin{array}{r}-0.013 \\
(.221)\end{array}$ \\
\hline January*Inside 10 Miles $^{*}$ State $_{\mathrm{j}}\left(\beta_{3}\right)$ & $\begin{array}{l}-0.047 \\
(.078)\end{array}$ & $\begin{array}{c}-0.069 \\
(.103)\end{array}$ & $\begin{array}{c}-0.086 \\
(.197)\end{array}$ & $\begin{array}{c}-0.015 \\
(.190)\end{array}$ \\
\hline January $^{*}$ Inside 25 Miles $^{*}$ State $_{\mathrm{j}}\left(\beta_{3}\right)$ & $\begin{array}{l}-0.065 \\
(.075)\end{array}$ & $\begin{array}{l}-0.01 \\
(.095)\end{array}$ & $\begin{array}{c}-0.086 \\
(.197)\end{array}$ & $\begin{array}{l}-0.028 \\
(.142)\end{array}$ \\
\hline
\end{tabular}

$\mathrm{N}=446$ in all specifications

Notes: Results include the full sample of stores in Wisconsin for which we have data on in at least one period. All Regressions include the January indicator as well as grocery, tobacco and national chain variables, the convenience store dummy is excluded, results are not sensitive to which dummy variable is excluded. Results reflect separate regressions for each distance measure and each state border using only stores in Wisconsin, the $\beta_{2}$ and $\beta_{3}$ coefficients for a given distance and state are reported for each separate regression. Asterisks denote significance at the $1 \%\left({ }^{* *}\right)$ and $10 \%\left(^{*}\right)$ levels.

estimates for stores near the state border suggest that the degree of over-shifting is sensitive to being near the Minnesota or Michigan state borders. Our primary estimates are similar in magnitude to Keeler et al. (1996) that suggest a $\$ 1$ increase in the tobacco tax increases the price of cigarettes by $\$ 1.11$. This is encouraging, considering that Keeler et al. use annual state level data (from 1960-1990) and identify the parameter of interest from a series of state tax changes. However, both the Keeler et al. estimate and the estimates presented in this paper are substantially smaller than the estimate by Harris (1987) that suggests a $\$ 1$ increase in the cigarette tax would result in a retail price increase of over $\$ 2$.
Our estimation strategy offers several advantages over those used in the previous studies. First, because we use micro-level data from retail locations we are able to accurately match county and city taxes to our observations. This is in sharp contrast to previous studies that use state-year level observations that cannot separate city and county level taxes or differentiate when during the year a tax is imposed. This is particularly important considering that county taxes are as much as $\$ 2$ per pack, city taxes are as much as 68 cents per pack in our sample, and tobacco prevention groups estimate at least 450 jurisdictions nationwide have a separate tax on tobacco. ${ }^{20}$

\footnotetext{
20 See Research Center for Tobacco Free Kids, "Research Center Fact Sheets," http:/ / www.tobaccofreekids.org/ research/factsheets/index.php?CategoryID=18.
} 
Second, we are able to use an isolated policy change that offers clean identification of the tobacco tax increase on retail prices. We discuss the robustness of this strategy in the following section, but it is noteworthy that tobacco tax increases could become law at the same time as other prevention methods or policies that may affect the demand for cigarettes (an alcohol tax change for instance). Lastly, our data come from an extremely short time window and relatively small geographic area compared to studies that use state-year variation. This is advantageous as we do not have to correct for inflation over time or adjust for changes in the cost of living when we use the difference-indifference method.

Over-shifting of the tobacco tax is consistent with over-shifting found in studies of alcohol tax incidence; however alcohol tax studies generally find a substantially larger amount of over-shifting. ${ }^{21}$ Young and Bielinska-Kwapisz (2002) use state-year tax variation to identify the incidence of alcohol taxation and find that it is over-shifted to consumers by as much as 186 percent of the tax. Kenkel (2005) uses a 2002 alcohol tax increase in the state of Alaska as a natural experiment to calculate the incidence of taxation on beer, wine and spirits. Kenkel finds that alcohol taxes are more than fully shifted to consumers across multiple brands and types of alcohol, and that for some brands the amount of over-shifting is more than 400 percent of the tax. Rojas (2008) uses the 1991 increase in the federal excise tax on beer as a natural experiment to assess a variety of pricing models in the beer industry; his work implies that beer taxes are more than fully passed on to consumers by as much as 237 percent of the tax.
Generally the empirical work on gasoline excise taxes shows that these taxes are not over-shifted to consumers. Chouinard and Perloff (2004) estimate the incidence of gasoline taxes and find that a 1 cent increase in the federal tax raises the retail price by 0.47 cents, but that an increase in the state gasoline tax by 1 cent raises the retail price by 1.01 cents. Doyle and Samphantharak (2008) use suspensions and subsequent reinstatements of the gasoline sales taxes in Illinois and Indiana as natural experiments to estimate the incidence of gasoline taxation and find less than full shifting of the tax to consumers. In addition, they find some evidence that suggests stores react differently to tax changes as the distance from the state border increases. Alm, Sennoga, and Skidmore (2009) use monthly data from ACCRA over the period 1984-1999 to estimate that gasoline taxes are fully shifted to consumers.

Economic theory suggests that in a perfectly competitive market with constant marginal costs, excise taxes will be fully passed to consumers but never over-shifted. Over-shifting results are often explained using models of imperfect competition. These models, advanced by Delipalla and Keen (1992), and Anderson, de Palma, and Kreider (2001), show how the type of product (homogeneous or differentiated), the type of imperfect competition (Bertrand, Cournot, oligopoly), and the demand elasticity for the product explain the incidence of per unit and ad valorem taxes.

Anderson, de Palma, and Kreider (2001) show that in markets with a differentiated product where the sellers have an oligopoly, firms engage in price or Bertrand competition, and a unit tax is imposed, the tax can be over-shifted to consumers in the form of higher prices. ${ }^{22}$

\footnotetext{
21 Estimates on the incidence of general sales taxes find that the amount of tax burden passed on to consumers varies substantially across the type of product used to create the estimates, although some estimates show evidence of substantial over-shifting as shown by Besley and Rosen (1999) and Poterba (1996).

22 Anderson, de Palma, and Kreider (2001) also show this result holds if firms compete by changing output, or in a Cournot game.
} 
The intuition behind this result is that in Bertrand competition, a given firm's best response, or reaction function, to a price increase of a competitor is to also increase prices. A tax increase can be thought of as a price increase by one firm that causes subsequent price increases of other firms. Firms increase their own prices because of the higher cost imposed by the tax; this effect is magnified because they are reacting to the higher price they observe from competitors, resulting in over-shifting of the tax to consumers. The degree of the over-shifting of the tax in this case depends on the slope of the firms' reaction functions, or how much they increase price in response to other firm's price increases. This explanation is intuitive, however; for over-shifting to occur the model requires the product demand elasticity to be less than negative one. ${ }^{23}$ This requirement is not likely to be met in the case of cigarettes as estimates of the price elasticity of demand for cigarettes, as reviewed by Chaloupka and Warner (2000), fall between -0.30 and -0.50 .

The Delipalla and Keen (1992) model requires a homogenous product, where the sellers have an oligopoly, and firms can enter the market freely (so that there are no profits). This model fits the empirical elasticity of demand estimates better, as over-shifting of a per-unit tax (assuming that firms have constant marginal cost of production) will occur as long as the product demand elasticity is less than zero. ${ }^{24}$ Although the Delipalla and Keen model fits the empirical work better, the assumption of a homogenous product may be strong in the case of cigarettes depending on if consumers view brands as different products, as there are 278 brands of cigarettes certified for sale in Wisconsin..$^{25}$

The Delipalla and Keen model is also helpful in understanding the differences in some of our incidence estimates between generic and name brand cigarettes. ${ }^{26}$ One explanation for this difference is that the demand elasticity is different for name brand and generic cigarettes. Using the Delipalla and Keen formula for overshifting ${ }^{27}$ the amount of over-shifting difference we observe in the full panel (Table 5 , column 1) implies that generic brand cigarettes have a demand elasticity that is -0.29 and that name brand cigarettes have a demand elasticity that is $-0.22 .{ }^{28}$ This result implies that consumers are more sensitive to price changes in generic brand cigarettes. This is somewhat counter-intuitive if generic and name brand cigarette consumers are the same group. However, if these groups are different sets of consumers the generic consumer group may be more price sensitive if they have lower incomes. Alternatively, name-brand smokers may have preferences for smoking that are shaped by brand loyalty, making them less price sensitive than generic brand smokers.

A second theoretical explanation for our empirical findings is the model proposed

\footnotetext{
23 Young and Bielinska-Kwapiza (2002) also offer an explanation of over-shifting that requires the product demand elasticity to be less than negative one.

${ }^{24}$ Cotterill, Egan, and Buckhold (2001) offer an explanation of over-shifting that only requires negative demand elasticity that is constant where the degree of over-shifting is also a function of the number of sellers.

25 See Wisconsin Department of Justice, "Directory of Certified Tobacco Manufacturers and Brands," http:// www.doj.state.wi.us/dls/tobacco/index.html.

26 Although many of the incidence point estimates for the name brand cigarettes are within the 95 percent confidence interval of the generic brand estimates (and vice versa), some of our primary results using panel data suggest that tax incidence is statistically different for generic and name brand cigarettes.

27 Assuming that firms have constant marginal costs the rate of over-shifting, $\mathrm{R}$ is defined as $\mathrm{R}=2 /(2-(\lambda \mathrm{E} / \mathrm{n}))$, where $\mathrm{n}$ is the number of sellers, $\lambda$ is the change in industry output that occurs for a given firms change in output and $\mathrm{E}$ is the absolute value of demand elasticity.

${ }^{28}$ For this calculation we impose the additional assumption that firms react identically to a change in industry output so that $\lambda=\mathrm{n}$, as described in Delipalla and Keen.
} 
by Becker, Grossman, and Murphy (1994). Becker, Grossman, and Murphy propose that because cigarette companies work as an oligopoly, they obtain maximum profit by raising the price of their product on addicted smokers, or those who have relatively inelastic demand and will continue to smoke even after a tax increase. Cigarette sellers realize that they will lose casual or new smokers as a result of the tax increase. However, the profit gained from increasing the price paid by addicted smokers will offset the future losses from reduced smoking by the casual or new smokers that results from the price increase in excess of the amount of the tax. Although the Becker, Grossman, and Murphy model may explain some of the price increase resulting from a tobacco tax increase, it does not guarantee over-shifting like the Delipalla and Keen and Anderson, de Palma, and Kreider models do for certain demand elasticities.

Finally, some of the over-shifting of the cigarette tax in Wisconsin could be the result of retailers using a simple costplus pricing mechanism. Wisconsin has a "minimum mark up" law on retail sales of cigarettes (The Unfair Sales Act, Wis. Stats s 100.30). This law requires retail cigarette venders to sell cigarettes for at least 6 percent more than the cost, including the tobacco tax, of buying them from a wholesaler or manufacturer. Because of this law, retailers would require a cost adjustment from wholesalers to legally adjust their prices by less than the amount of the tax increase. If wholesalers do not adjust cost, and retailers increase the price by the amount of the tax plus the minimum mark-up we would expect that the tax to be passively over-shifted in the form of higher prices. This might account for some, but not all, of the over-shifting that we observe.

\section{Methodology Concerns and Robustness Checks}

There are two main criticisms of our methodology for identifying the incidence of tobacco taxation that we have not yet addressed. The first is that although we look at prices in Wisconsin before and after the tax change, we cannot rule out that there are other factors that are causing prices to change besides the tax increase. The second is that retail cigarette outlets in Wisconsin may be changing the price of their product prior to the date of the tax increase in response to the looming law change and that this response biases our estimates.

The difference-in-differences identification strategy we use assumes that the price change that would have occurred in Wisconsin in the absence of the tax change is equal to the price change that actually occurred over the same time period in the Border States. We believe that our assumption is reasonable considering that the average price change in Border States for name brand cigarettes was less than 1 cent and for generic brand cigarettes was 1 cent. This does not, however, rule out that other factors in Wisconsin changed during the period covered by our data.

We are aware of one minor law change in Wisconsin that may have altered the price of cigarettes in addition to the tax increase. Beginning January 1, 2008, Wisconsin began offering a free two-week supply of tobacco cessation medication to anyone requesting it through a tollfree phone call. The medication includes nicotine patches, gum and lozenges. ${ }^{29}$ The offer is for a one-time supply and ranges in value between $\$ 50-100$. According to conversations with administrators at Wisconsin's Office of Tobacco Prevention and Control, only 7,768 medication packets were distributed in January, 2008.

29 See University of Wisconsin Center for Tobacco Research and Intervention, “Quit Line," at http://www.ctri. wisc.edu/. 
Considering that there are approximately 1.1 million smokers in Wisconsin, the tobacco cessation medication program reached far less than one percent of the smoking population. We believe that any potential bias in our estimates from this program would work toward lowering our estimated coefficients. We are not aware of any other law change or trends that would affect our results.

We also examined whether the possibility that firms might alter their prices in anticipation of tax change might be a serious problem. Specifically, we administered a secondary survey of establishments in our sample to ask them about this possibility. We randomly selected 50 stores in Wisconsin from our sample and asked them about the timing of their price changes as a result of the tax increase. Specifically, we asked the establishment manager if they had changed prices on exactly January 1, 2008. Of the 50 store managers surveyed, 49 stated that they had changed prices exactly on January 1 . The lone exception stated that they had waited until about a week after January 1 to increase prices. We also asked if they had changed cigarette prices prior to the January 1 tax policy change. None of the 50 respondents in our survey stated that they changed prices in anticipation of the tax change. Although the sample size is quite small, these survey results support our assumption that cigarette prices did not change in anticipation of the tax change.

\section{CONCLUSION}

Tobacco taxes represent about $\$ 22$ billion dollars annually in federal and state government revenues. Although the statutory incidence of these taxes falls on tobacco sellers, the economic incidence is often assumed to fall largely on tobacco consumers. The evidence presented in this paper suggests that not only do consumers pay the entire economic burden of the tobacco tax, but that they also pay a premium in addition to the amount of tax. We find that the incidence of tobacco taxation is over-shifted to consumers by between 8-17 percent of the amount of the tax. This amount of over-shifting is similar to that found by Keeler et al. (1996), although our data and methodology differ substantially. The over-shifting we find is substantially smaller than the over-shifting of general sales taxes that Besley and Rosen (1999) find for some products (such as bread and underwear). The smaller over-shifting that we find is consistent with consumers being relatively more price sensitive for cigarettes compared with the necessitytype products with few (if any) substitutes that find larger amounts of over-shifting.

It seems that over-shifting of the tax is aiding policy makers in reducing consumption of cigarettes in Wisconsin. Data on the amount of cigarettes purchased in Wisconsin show that cigarette sales have declined since the introduction of the tax. The number of packs of cigarettes sold in Wisconsin decreased from 394 million in 2007 to 335 million in $2008,{ }^{30}$ a decline of nearly 59 million packs. ${ }^{31}$ The reduction in cigarettes purchased was not enough to offset revenue gains from the increased amount of tax, as tax revenues from cigarette sales in Wisconsin increased from \$298 million 2007 to \$589 million in 2008 .

Our paper is unique in that we are able to estimate how the incidence of a cigarette tax depends on the distance that a retail location is from the border of a state where taxes are different. We show that the amount of over-shifting is in fact

\footnotetext{
30 This information was obtained through personal correspondence with the Wisconsin Department of Revenue.

31 We hesitate to infer causality, as we are not making this comparison with neighboring states that may be affected by similar overall trends in cigarette purchases. It is also possible that the decreased purchases in Wisconsin are offset by increased smuggling across state borders.
} 
sensitive to how far a retail establishment is from a state border. The amount of overshifting is between 53-71 percent less for stores near the Minnesota border (where the tobacco tax is lower after the tax change in Wisconsin). In contrast, stores near the Michigan border (where the tobacco tax is higher before and after the law change) gain at least 93 percent and at most 149 percent of the over-shifting premium. The difference in over-shifting premiums is consistent with recent evidence presented by Lovenheim (2008) on casual cigarette smuggling across state borders. The relationship between cigarette prices, smuggling, and distance to a state's border suggests that policy makers may want to coordinate tax rates or tax rate increases with neighboring states if the goal is to reduce tobacco consumption.

\section{ACKNOWLEDGMENTS}

We would like to thank James Puckett for GIS assistance, Reshad Ahsan, T.J. Brooks, Jeff Kubik, Kevin McGee, Jon Rork, David Sjoquist, Kurt Schnier, Geoffrey Turnbull, Participants at the Public Finance Workshop at Georgia State University, Department Seminar Participants at the University of Wisconsin-La Crosse, George Zodrow and two anonymous referees for helpful comments, also David Ahrens and Deb Klimke at the Wisconsin Department of Revenue, Administrators at Illinois Department of Revenue, Minnesota Department of Revenue, Iowa Department of Revenue, Michigan Department of Revenue, and at Wisconsin's Office of Tobacco Prevention and Control for assistance in data collection.

\section{REFERENCES}

Alm, James, Edward Sennoga, and Mark Skidmore, 2009.

"Perfect Competition, Urbanization, and Tax Incidence in the Retail Gasoline Market." Economic Inquiry 47 (1), 118-134.
Anderson, Simon, Andre' de Palma, and

Brent Kreider, 2001.

"Tax Incidence in Differentiated Product Oligopoly." Journal of Public Economics 82 (2), 173-192.

Ashenfelter, Orley, and Daniel Sullivan, 1987. "Nonparametric Tests of Market Structure: An Application to the Cigarette Industry." Journal of Industrial Economics 35 (4), 483-498. Baltagi, Badi H., and Dan Levin, 1986.

“Estimating Dynamic Demand for Cigarettes Using Panel Data: The Effects of Bootlegging, Taxation and Advertising Reconsidered." The Review of Economics and Statistics 68 (1), 148-155.

Becker, Gary S., Michael Grossman, and

Kevin Murphy, 1994.

"An Empirical Analysis of Cigarette Addiction." American Economic Review 84 (3), 396-418.

Besley, Timothy, and Harvey S. Rosen, 1999.

"Sales Taxes and Prices: An Empirical Analysis." National Tax Journal 52 (2), 157-178.

Chaloupka, Frank J., and Kenneth E. Warner, 2000.

"The Economics of Smoking." In Culyer, Anthony, and Joseph Newhouse (eds.), The Handbook of Health Economics, v.1B, 1539-1627. Elsevier, Amsterdam.

Chouinard, Hayley, and Jeffrey M. Perloff, 2004. "Incidence of Federal and State Gasoline Taxes," Economic Letters 83 (1), 55-60.

Cotterill, Ronald, Leonard Egan, and William Buckhold, 2001.

"Beyond Illinois Brick: The Law and Economics of Cost Pass-Through in the ADM Price Fixing Case." Review of Industrial Organization 18 (1), 45-52.

Cutler, David M., Arnold M. Epstein, Richard Frank, Raymond Hartman, Charles King III, Joseph P. Newhouse, Meredith B. Rosenthal, and Elizabeth Richardson Vigdor, 2000.

"How Good Was the Tobacco Settlement? Assessing Payments to Massachusetts." Journal of Risk and Uncertainty 21 (2-3), 235-261.

Cutler, David M., 2002.

"Health Care and the Public Sector." In Auerbach, Alan J., and Martin Feldstein (eds.), Handbook of Public Economics, 2145-2243. Elsevier. Amsterdam. 
Delipalla, Sophia, and Michael Keen, 1992.

"The Comparison Between Ad Valorem and Specific Taxation Under Imperfect Competition." Journal of Public Economics 49 (3), 351368.

Doyle Jr., Joseph J., and Krislert

Samphantharak, 2008.

"\$2.00 Gas! Studying the Effects of a Gas Tax Moratorium." Journal of Public Economics 92 (3-4), 869-884.

Evans, William, Jeanne S. Ringel, and Diana Stech, 1999.

"Tobacco Taxes and Public Policy to Discourage Smoking." In Poterba, James M. (ed.), Tax Policy and the Economy, 1-55. MIT Press, Cambridge, MA.

Fullerton, Don, and Gilbert E. Metcalf, 2002.

"Tax Incidence." In Auerbach, Alan J., and Martin Feldstein (eds.), Handbook of Public Economics, 1787-1872. Elsevier, Amsterdam.

Gravelle, Jane G., 2007.

"The Cigarette Tax Increase to Finance SCHIP." CRS Report RS22681. Congressional Research Service, Washington, DC.

Gravelle, Jane, and Dennis Zimmerman, 1994.

"Cigarette Taxes to Fund Health Care Reform: An Economic Analysis." CRS Report 94214. Congressional Research Service, Washington, DC.

Gruber, Jonathan, and Botond Koszegi, 2001.

"Is Addiction Rational? Theory and Evidence." Quarterly Journal of Economics 116 (4), 1261-1303.

Gruber, Jonathan, Anindya Sen, and Mark

Stabile, 2003.

"Estimating Price Elasticities When There Is Smuggling: The Sensitivity of Smoking to Price in Canada." Journal of Health Economics 22 (5) 821-842.

Harris, Jeffrey E., 1987.

"The 1983 Increase in the Federal Cigarette Excise Tax." In Summers, Lawrence H. (ed.), Tax Policy and the Economy, 87-111. MIT Press, Cambridge, MA.
Keeler, Theodore E., Teh-wei Hu, Paul G. Barnett, Willard G. Manning, and Hai-Yen Sung, 1996.

"Do Cigarette Producers Price-Discriminate by State? An Empirical Analysis of Local Cigarette Pricing and Taxation." Journal of Health Economics 15 (4), 499-512.

Kenkel, Donald S., 2005.

"Are Alcohol Tax Hikes Fully Passed Through to Prices? Evidence from Alaska." American Economic Review Papers and Proceedings 95 (2), 273-277.

Lovenheim Michael F., 2008.

"How Far to the Border?: The Extent and Impact of Cross-Border Casual Cigarette Smuggling." National Tax Journal 61 (1), 7-33. Manning, Willard G., Emmett B. Keeler, Joseph P. Newhouse, Elizabeth M. Sloss, and Jeffrey Wasserman, 1989.

"Taxes of Sin: Do Smokers and Drinkers Pay Their Own Way?" Journal of the American Medical Association 261 (11), 1604-1609.

Manning, Willard G., Emmett B. Keeler, Joseph P. Newhouse, Elizabeth M. Sloss, and Jeffrey Wasserman, 1991.

The Costs of Poor Health Habits. Harvard University Press, Cambridge, MA.

Poterba, James M., 1989.

"Lifetime Incidence and the Distribution Burden of Excise Taxes" American Economic Review 79 (2), 325-331.

Poterba, James M., 1996.

"Retail Price Reactions to Changes in State and Local Sales Taxes." National Tax Journal 49 (2), 165-176.

Rojas, Christian, 2008.

"Price Competition in U.S. Brewing." Journal of Industrial Economics 56 (1), 1-31.

Shoven, John B., Jeffrey O. Sundberg, and John P. Bunker, 1989.

"The Social Security Cost of Smoking." In Wise, David (ed.), Economics of Aging, 231-251. University of Chicago Press, Chicago.

Sloan, Frank A., Jan Ostermann, Gabriel

Picone, Christopher Conover, and Donald $\mathrm{H}$. Taylor, Jr. 2004.

The Price of Smoking. MIT Press, Cambridge, MA. 
Stehr, Mark, 2005.

"Cigarette Tax Avoidance and Evasion." Journal of Health Economics 24 (2), 278-297.

Sumner, Daniel A., and Michael K. Wohlgenant, 1985.

"Effects of an Increase in the Federal Excise Tax on Cigarettes." American Journal of Agricultural Economics 67 (2), 235-242.

Viscusi, Kip W., 1995.

"Cigarette Taxation and the Social Consequences of Smoking." In Poterba, James M. (ed.), Tax Policy and the Economy, 51-101. MIT Press, Cambridge, MA.
Viscusi, Kip W., 2002.

Smoke-Filled Rooms: A Postmortem on the Tobacco Deal. University of Chicago Press, Chicago.

Viscusi, Kip W., and Joni Hersch, 2008.

"The Mortality Cost to Smokers." NBER Working Paper No. 13599. National Bureau of Economics Research, Cambridge, MA.

Young, Douglas J., Agnieszka Bieliszka-

Kwapisz, 2002.

"Alcohol Taxes and Beverage Prices." National Tax Journal 55 (1), 57-73. 